\title{
REDOX STATUS IN PATIENTS WITH FEMORAL NECK FRACTURES
}

Goran Pesic ${ }^{1}$, Jovana Jeremic ${ }^{2}$, Isidora Stojic ${ }^{2}$, Aleksandra Vranic ${ }^{2}$, Marija Cankovic ${ }^{2}$, Tamara Nikolic ${ }^{2}$, Nevena Jeremic ${ }^{2}$,

Aleksandar Matic ${ }^{3}$, Ivan Srejovic ${ }^{4}$, Vladimir Zivkovic ${ }^{4}$, Vladimir Jakovljevic ${ }^{4}$ ${ }^{1}$ Orthopedic and Traumatology Clinic, Podgorica, Montenegro

${ }^{2}$ Department of Pharmacy, Faculty of Medical Sciences, University of Kragujevac, Kragujevac, Serbia

${ }^{3}$ Department of Orthopedics, Clinical Center of Kragujevac, Kragujevac

${ }^{4}$ Department of Physiology, Faculty of Medical Sciences, University of Kragujevac, Kragujevac, Serbia

\author{
REDOKS STATUS PACIJENATA SA PRELOMOM VRATA FEMURA

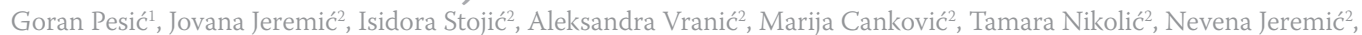 \\ Aleksandar Matić3 , Ivan Srejović ${ }^{4}$, Vladimir Živković ${ }^{4}$, Vladimir Jakovljevićc \\ ${ }^{1}$ Klinika za ortopediju i traumatologiju, Podgorica, Crna Gora \\ ${ }^{2}$ Katedra za Farmaciju, Fakultet medicinskih nauka u Kragujevcu, Kragujevac, Srbija \\ ${ }^{3}$ Klinika za ortopediju, Klinički Centar Kragujevac, Kragujevac \\ ${ }^{4}$ Katedra za Fiziologiju, Fakultet medicinskih nauka u Kragujevcu, Kragujevac, Srbija
}

Received / Primljen: 06.11.2015.

Accepted / Prihvaćen: 22.12.2015.

\begin{abstract}
The femur transfers the body weight from the pelvic bone to the shinbone. Femur fractures are a significant cause of morbidity and mortality among the group of locomotor apparatus injuries, especially in the elderly population. Considering that oxidative stress occurs as a result of increased production of free radicals that damage cell function and cause numerous pathological conditions and diseases, the aim of this study was to investigate oxidative stress parameters in older patients with femoral neck fractures. This clinical study included 70 patients, of which 35 had femoral neck fractures (26 males and 9 females), while the other half of the patients formed the matched control group. Markers of oxidative stress $\left(\mathrm{NO}_{2}\right.$, TBARS, $\mathrm{H}_{2} \mathrm{O}_{2}$ and $\left.\mathrm{O}_{2}^{-}\right)$and antioxidative enzymes (SOD, CAT, and GSH) were measured. Results showed that the levels of $\mathrm{O}_{2}^{-}$increased, while levels of $\mathrm{NO}_{2}, \mathrm{H}_{2} \mathrm{O}_{2}$ and all the antioxidative enzymes decreased in patients with femoral neck fractures. These findings indicate that fractures cause oxidative stress, probably because of the reduced activity of osteoblasts and the increased activity of osteoclasts.
\end{abstract}

Keywords: Oxidative stress, Antioxidant enzymes, Fracture, Femoral neck

\section{SAŽETAK}

Femur je parna kost i ima ulogu da prenese težinu tela sa karlične kosti na golenjaču. Prelomi femura predstavljaju značajan uzrok morbiditeta i mortaliteta u grupi povreda lokomotornog aparata, posebno kod starije populacije. Sobzirom da je poznato da oksidacioni stres nastaje kao posledica prekomerne produkcije slobodnih radikala koji oštećuju ćelijsku funkciju $i$ dovode do nastanka mnogih patoloških stanja i bolesti, cilj ovog istraživanja bio je da se ispitaju parametri oksidacionog stresa kod starijih pacijenata sa preloma vrata butne kosti. Ova prospektivna klinickka studija je obuhvatila 70 ispitanika. Prelom vrata butne kosti imalo je 35 pacijenata (26 - muškaraca; 9 žena), dokje druga polovina pacijenata istog pola, starosti i karakteristika predstavljala kontrolnu grupu. Markeri oksidacionog stresa $\left(\mathrm{NO}_{2}\right.$, TBARS, $\left.\mathrm{H}_{2} \mathrm{O}_{2} i \mathrm{O}_{2}^{-}\right) \mathrm{i}$ antioksidacioni enzimi (SOD, CAT, GSH) su odredivani spektrofotometrijski. Rezultati su pokazali da je nivo $\mathrm{O}_{2}^{-}$povećan, dok su nivoi $\mathrm{NO}_{2}, \mathrm{H}_{2} \mathrm{O}_{2} i$ svi antioksidacioni enzimi smanjeni kod pacijenata sa preloma vrata butne kosti. Ovi rezultati pokazuju da prelom uzrokuje nastanak oksidacionog stresa, najverovatnije zbog smanjene aktivnosti osteoblasta i povećane aktivnosti osteoklasta.

Ključne reči: Oksidacioni stres, Antioksidativna zaštita, Prelom, Vrat butne kosti

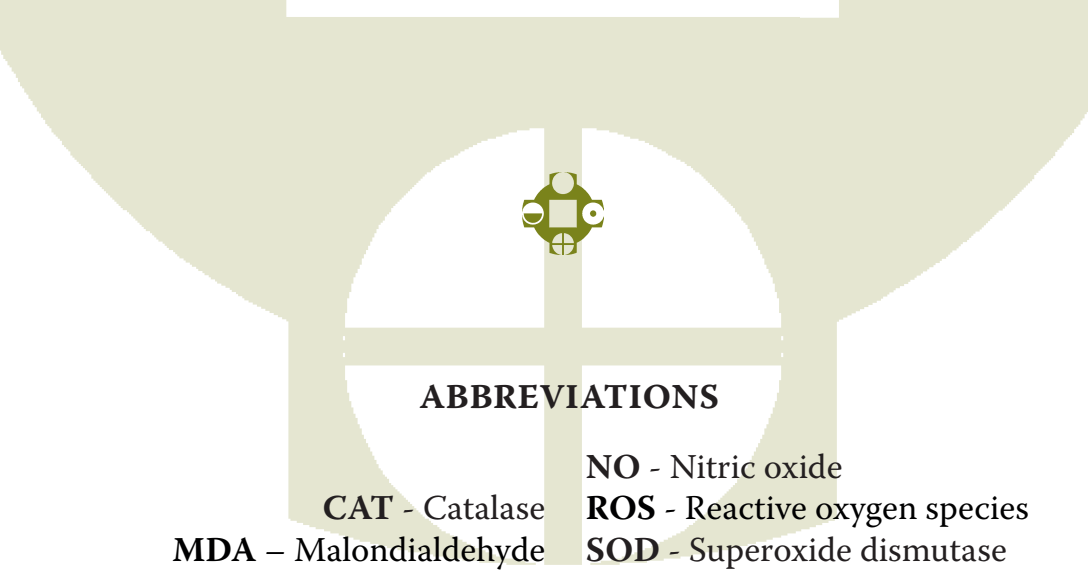

UDK: 616.718.4-001.5 / Ser J Exp Clin Res 2016; 17 (3): 199-205 DOI: 10.1515/SJECR-2015-0061

Corresponding author: Vladimir Jakovljevic, $\mathrm{MD}, \mathrm{PhD}$ 


\section{INTRODUCTION}

The femur is the longest, strongest and largest bone in the human body. It transfers the body weight from the pelvic bone to the shinbone (1). Femur fractures are a significant cause of morbidity and mortality among the locomotor apparatus injuries, especially in the elderly population (2). Although any part of this bone can break, the femoral neck or hip is the most common part to fracture (3). The number of femoral fractures is increasing, and this trend will continue. In particular, higher incidences of hip fractures are recorded in the Scandinavian countries, the United States and Western Europe, while the rate is much lower in the Far East and Africa $(4,5)$. The factors contributing to this epidemic include, the length of time since the implantation of a prosthesis, loose stems and an aging population. Because of these factors, a large number of hip arthroplasties are performed each year (6). In young patients, femur fractures occur very rarely, and when they do, they occur due to major trauma (traffic accidents, fall from heights). Femur fractures occur more frequently in the elderly (over sixty-five years), where trauma plays a less significant role but factors such as low mineral density due to osteoporosis, osteopenia, or muscle atrophy play important roles (7). The main signs of fracture are pain and functional impotence. The patient cannot actively raise either the injured limb or their heel from the ground (8).

Considering that oxidative stress occurs as a result of the increased production of free radicals that damage cell function and cause many pathological conditions and diseases, it is not surprising that in recent years, its role has been increasingly examined in a variety of fractures. Data from existing literature has shown that reactive oxygen species (ROS) in physiological conditions contribute to the destruction of calcified tissue (9). Some studies have found that increased production of free radicals is associated with reduced bone density (10). Additionally, the increased activity of osteoclasts and decreased activity of osteoblasts may contribute to the imbalance between pro-oxidants and antioxidants in patients with various broken bones (11). In a study, Yeler and coworkers have shown that the production of free radicals is highest immediately after the fracture and continues for several months during the period of healing (12).

Despite extensive research, the impact of free radicals and antioxidant enzymes on fractures and whether the ROS production exceeds the antioxidant enzyme activity has not been fully understood. Based on the above data, the aim of this study was to investigate oxidative stress parameters in older patients with femoral neck fractures.

\section{MATERIALS AND METHODS}

\section{Subjects}

The prevalence study included 70 patients, of whom 35 patients had femoral neck fractures $(26$ males and 9 females), while the other half of the patients were matched with regard to sex, age and other characteristics and designated as the control group. The average age of the patients with femoral neck fractures is 66 years (women - 65.9 years; males - 66.1 years). All patients with fractures were admitted to the orthopaedic ward of the Clinical Center in Kragujevac during the period from February 2015 to May 2015.

All subjects were over 60 years old, and all patients from experimental group showed indications that required surgical intervention. The exclusion criteria included a lack of thigh/lower leg, a stump unsuitable for prosthesis (a stump with trophic changes due to islands, ulcer, fistula, a painful neuroma, deformities stump, extensive scarring, or extreme muscle atrophy), damage to the spinal cord or peripheral nerve injury (quadriplegia, paraplegia and hemiplegia) with or without loss of control of urination and defecation, and tertiary stages of malignant diseases.

All patients were familiarized with the study's protocol and their written consent was obtained. The study was approved by the Ethical committee of the Clinical Center of Kragujevac, Kragujevac.

\section{The study protocol}

This was a prospective clinical study conducted from February 2015 to June 2015.

The venous blood samples from subjects in the control group were obtained only once. Blood samples were taken from the patients in the experimental group during the first 12 hours after a femoral neck fracture. All blood samples were collected from the antecubital veins into Vacutainer test tubes containing sodium citrate anticoagulant. Blood was centrifuged to separate plasma and red blood cells (RBCs). Isolated RBCs were washed three times with three volumes of ice-cold $0.9 \mathrm{mmol} / \mathrm{L}$ $\mathrm{NaCl}$, and haemolysates containing approximately $50 \mathrm{~g} \mathrm{Hb} / \mathrm{L}$ were used in the determination of antioxidant enzymes.

\section{Biochemical assays}

The following markers were measured from plasma: superoxide anion radical $\left(\mathrm{O}_{2}^{-}\right)$, hydrogen peroxide $\left(\mathrm{H}_{2} \mathrm{O}_{2}\right)$, index of lipid peroxidation (measured as TBARS), and nitric oxide (NO) in the form of nitrite $\left(\mathrm{NO}_{2}^{-}\right)$. The activities of antioxidant enzymes (superoxide dismutase (SOD), catalase (CAT) and reduced glutathione (GSH)) were determined in the haemolysates.

Biochemical analyses of oxidative stress parameters and antioxidant enzymes were conducted in the Laboratory of Cardiovascular Physiology at the Faculty of Medical Sciences in Kragujevac. The spectrophotometric measurements were conducted using the Shimadzu UV-1800 instrument, North America.

\section{Measurement of superoxide anion radical $\left(\mathrm{O}_{2}^{-}\right)$ concentration}

Determination of the superoxide anion radical $\left(\mathrm{O}_{2}{ }^{-}\right)$ concentration is based on the reaction of $\mathrm{O}_{2}^{--}$with nitro blue tetrazolium (NBT), which results in nitro blue forma- 
zan (13). The maximum absorption wavelength used for these measurements was $\lambda \max =550 \mathrm{~nm}$.

\section{Determination of the hydrogen peroxide $\left(\mathrm{H}_{2} \mathrm{O}_{2}\right)$}

concentration

Determination of the hydrogen peroxide $\left(\mathrm{H}_{2} \mathrm{O}_{2}\right)$ concentration is based on oxidation of phenol red using hydrogen peroxide, a reaction that is catalysed by the enzyme horseradish peroxidase (HRPO) (14). This reaction results in the formation of a compound that has a maximum absorption at wavelength $\lambda \max =610 \mathrm{~nm}$.

\section{Determination of the index of lipid peroxidation \\ (TBARS)}

The levels of lipid peroxidation were determined indirectly by measuring the products of lipid peroxidation reactions with thiobarbituric acid (Thiobarbituric Acid Reactive Substances - TBARS). This method is based on the determination of the levels of one of the lipid peroxides malondialdehyde (MDA) based on its reaction with thiobarbituric acid (TBA) (15). Distilled water was used as the blank probe. Measurements was obtained at a wavelength of $\lambda=530 \mathrm{~nm}$.

\section{Determination of nitrite $\left(\mathrm{NO}_{2}^{-}\right)$levels}

Nitric oxide $(\bullet \mathrm{NO})$ decomposes rapidly to form stable nitrite/nitrate metabolic products. The method for the detection of plasma nitrite levels is based on the Griess reaction. Nitrite $\left(\mathrm{NO}_{2}^{-}\right)$levels were determined as an index of $\mathrm{NO}$ production, which reacts with the Griess reagent to form a purple diazo-complex (16). Nitrites were measured at a wavelength of $550 \mathrm{~nm}$.

Determination of superoxide dismutase (SOD) activity

The determination of superoxide dismutase (SOD) activity is based on the epinephrine method. A mixture of $100 \mu \mathrm{L}$ lysate and $1 \mathrm{~mL}$ carbonate buffer was prepared, and $100 \mu \mathrm{L}$ of epinephrine was then added to the mixture. The detection was performed at a wavelength of $470 \mathrm{~nm}$. This method belongs to the 'negative type' group of methods, because it monitors the decrease in auto-oxidation speed in an alkaline medium, which is dependent on $\mathrm{O}_{2}$ - levels (17).

\section{Determination of catalase (CAT) activity}

The determination of catalase (CAT) activity in the sonificate is based on the methods described by Beutler $(18,19)$. The lysates were diluted with distilled water $(1: 7$ $\mathrm{v} / \mathrm{v})$ and treated with chloroform-ethanol $(0.6: 1 \mathrm{v} / \mathrm{v})$ to remove haemoglobin. Then, $50 \mu \mathrm{L}$ catalase buffer, $100 \mu \mathrm{L}$ sample, and $1 \mathrm{~mL} 10 \mathrm{mM} \mathrm{H}_{2} \mathrm{O}_{2}$ were added to the samples. The results were detected at a wavelength of $360 \mathrm{~nm}$. Distilled water was used as the blank probe (20).

\section{Determination of reduced glutathione (GSH) levels}

The reduced glutathione (GSH) concentration is determined spectrophotometrically using the Beutler method
(21). The absorbance (A) is measured at a maximum absorption wavelength of $\lambda \max =420 \mathrm{~nm}$.

\section{Statistical Analysis}

Statistical analysis was conducted using the statistical package SPSS 20.0 for Windows. The results are expressed as means \pm standard deviation of the mean (SD). The data distribution was analysed using the Shapiro-Wilk and Kolmogorov-Smirnov tests, and depending on the results, the appropriate parametric or nonparametric test was used. The alpha level for significance was set to $\mathrm{p}<0.05$.

\section{RESULTS}

$\mathrm{O}_{2}^{-}$levels

The values of $\mathrm{O}_{2}^{-}$levels were significantly higher in the experimental group compared to the control group ( $\mathrm{p}<$ 0.05) (Figure 1).

\section{$\mathrm{H}_{2} \mathrm{O}_{2}$ values}

The values of $\mathrm{H}_{2} \mathrm{O}_{2}$ levels were significantly lower in patients with femoral neck fractures compared with healthy subjects $(\mathrm{p}<0.01)$ (Figure 2$)$.

\section{TBARS values}

The values of TBARS were not statistically different in the experimental group compared with the control group $(\mathrm{p}>0.05)$ (Figure 3).

$\mathrm{NO}_{2}$ - levels

The values of $\mathrm{NO}_{2}$ - levels were significantly lower in patients with femoral neck fractures compared to healthy patients $(\mathrm{p}<0.01)$ (Figure 4$)$.

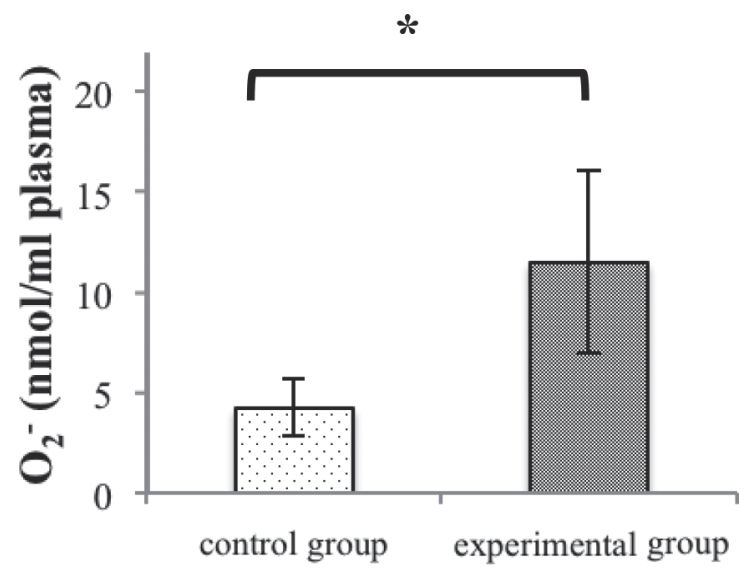

Figure 1. The values of superoxide anion radical levels in the control and experimental groups. The values are represented as $\mathrm{X} \pm \mathrm{SD}$; $\mathrm{X}$ - mean, $\mathrm{SD}$ - standard deviation; ${ }^{*} \mathrm{p}<0.05,{ }^{* *} \mathrm{p}<0.01$. 


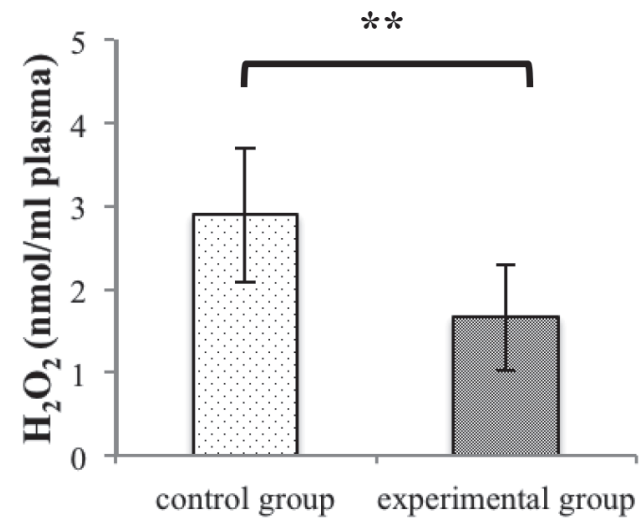

Figure 2. The values of hydrogen peroxide levels in the control and experimental groups. The values are represented as $\mathrm{X} \pm \mathrm{SD} ; \mathrm{X}-$ mean, SD - standard deviation; ${ }^{*} \mathrm{p}<0.05$, ${ }^{* *} \mathrm{p}<0.01$.

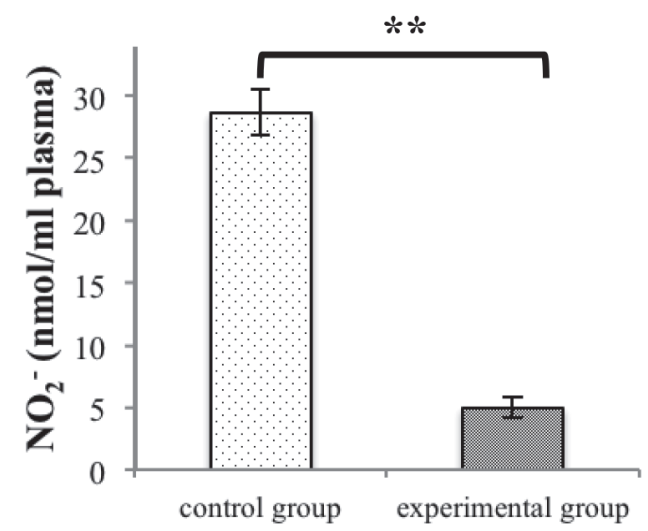

Figure 4. The values of nitric oxide levels in the control and experimental groups. The values are represented as $\mathrm{X} \pm \mathrm{SD} ; \mathrm{X}$ - mean, $\mathrm{SD}$ - standard deviation; * $\mathrm{p}<0.05$, ** $\mathrm{p}<0.01$.

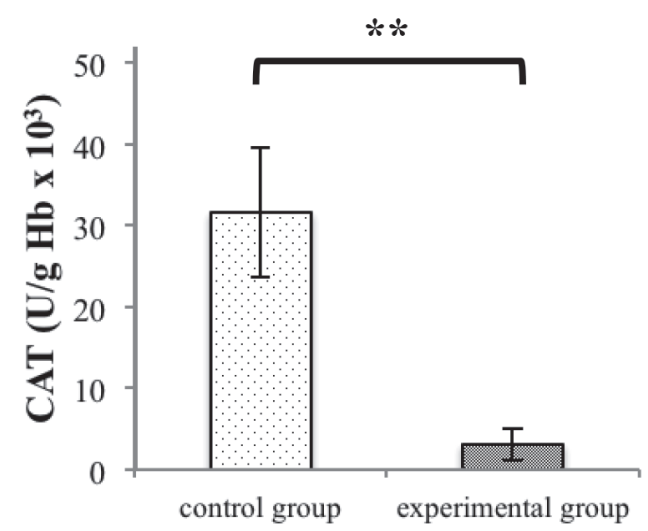

Figure 6. The values of catalase levels in control and experimental groups. The values are represented as $\mathrm{X} \pm \mathrm{SD}$; $\mathrm{X}$ - mean, $\mathrm{SD}$ - standard deviation; " $\mathrm{p}<0.05,{ }^{* * *} \mathrm{p}<0.01$.

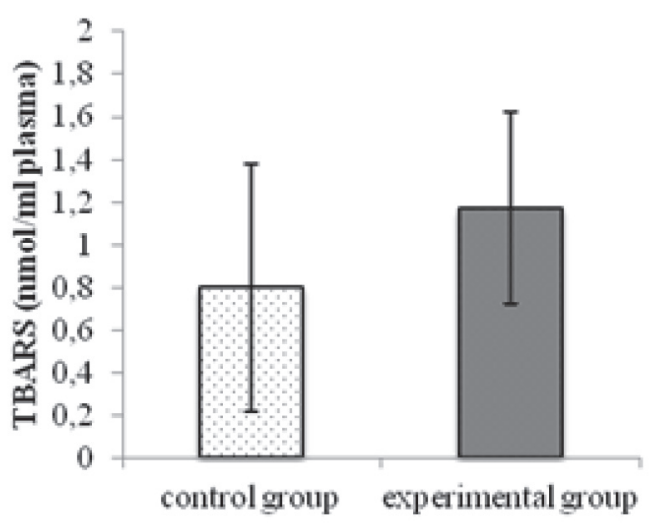

Figure 3. The values of lipid peroxidation (measured as TBARS) in the control and experimental groups. The values are represented as $\mathrm{X} \pm \mathrm{SD}$; $\mathrm{X}$ - mean, SD - standard deviation; ${ }^{*} \mathrm{p}<0.05$, ${ }^{* *} \mathrm{p}<0.01$.

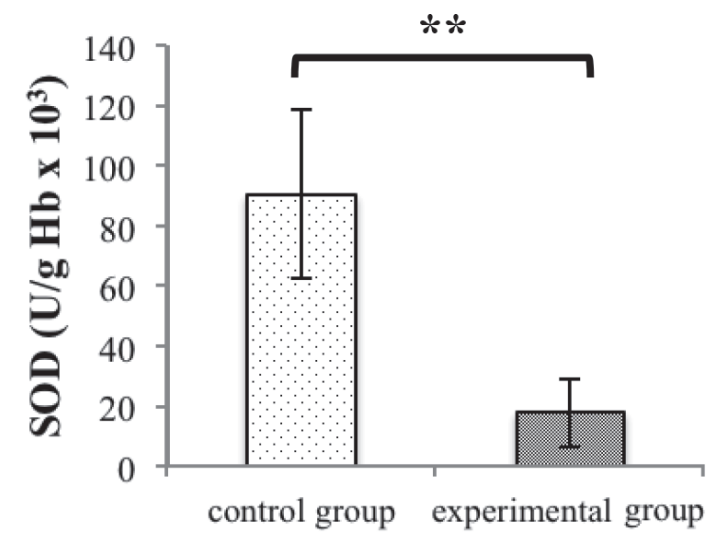

Figure 5. The values of superoxide dismutase levels in the control and experimental groups. The values are represented as $\mathrm{X} \pm \mathrm{SD} ; \mathrm{X}$ - mean, $\mathrm{SD}$ - standard deviation; ${ }^{*} \mathrm{p}<0.05,{ }^{* *} \mathrm{p}<0.01$.

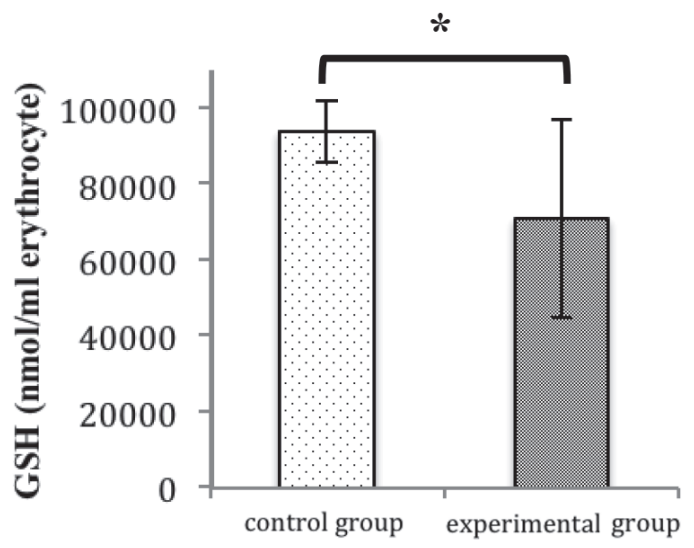

Figure 7. The values of reduced glutathione levels in the control and experimental groups. The values are represented as $\mathrm{X} \pm \mathrm{SD} ; \mathrm{X}$ - mean, $\mathrm{SD}$ - standard deviation; * $\mathrm{p}<0.05,{ }^{* * *} \mathrm{p}<0.01$. 
Values of antioxidative enzymes CAT, SOD and GSH

The values of all measured antioxidative enzymes were statistically lower in the experimental group compared to the control group $(\mathrm{p}<0.01)$ (Figure $5,6,7)$.

\section{DISCUSSION}

Fracture of the femoral neck (hip) is a typical fracture in elderly patients. Despite all the surgical achievements in recent years, hip fractures cause high rates of complications and thus increase disability, morbidity and mortality. One-third of the patients require a higher level of longterm care; furthermore, the death rate in the hospitals is approximately $10 \%$, and mortality during the first year of fracture is approximately $27 \%$ (22). As stated above, the risk of fractures is correlated with the age of the patient because any loss of osteoblasts or increase of osteoclasts leads to osteoporosis, lower bone density, decrease in bone mass and deterioration of bone, and thus results in an increased risk for fractures (9).

Considering these factors, the aim of this study was to investigate the value of the oxidative stress parameters and antioxidant enzymes in elderly patients with femoral neck fractures. We must note that many scientists believe that the damage caused by free radicals is the main factor that leads to aging of cells and tissues $(23,24)$. In fact, it is believed that free radicals damage cellular macromolecules, including proteins, lipids, and DNA, leading to aging and cell death. In addition, there is evidence to support that the aging of cells results in an imbalance between pro oxidants and antioxidants, and leads to the damage of cellular macromolecules (25). This theory explains why the values of oxidative stress parameters were increased in elderly patients.

In contrast to the several studies that have examined the impact of bone fractures in elderly patients on the immune system $(26,27)$, very few studies have tested their effects on redox status, which is discussed in this study.

During this study, we observed a statistically significant increase in the values of superoxide anion radicals in the experimental group compared to the control group (Figure 1). Opinions about the specific primary mechanisms that cause high concentrations of free radicals are divided. Some researchers believe that high concentrations of superoxide anion radicals is probably the result of the activities of numerous phagocytes including monocytes, macrophages and neutrophils, caused due to the fracture of the femur (28). Others believe that an increase in $\mathrm{O}_{2}^{-}$levels occurs as a result of bone resorption by osteoclasts (29). When bone fracture occurs, a remarkable yield of free radicals is generated by the damaged tissues. However, controlled production of free radicals by normally functioning osteoclasts can accelerate the destruction of calcified tissues and assist in bone remodelling. Enhanced osteoclastic activity observed in bone disorders and fractures may be responsible for increased production of reactive oxygen species (ROS) in the form of superoxide anion radicals
(30). Moreover, the inhibition of the activity of antioxidant enzymes, such as superoxide dismutase, was associated with increased $\mathrm{O}_{2}$ - production by the osteoclasts $(30,31)$. In the present study we found a significant decrease in the activity of SOD, which may be one of the potential reasons for the diminished decomposition of $\mathrm{O}_{2}{ }^{-}$and, therefore, its increased release.

Unlike the $\mathrm{O}_{2}^{-}$levels, the levels of hydrogen peroxide are lower in patients with femoral neck fractures compared to those who do not have a fracture (Figure 2). These results are puzzling, because the activity of both the enzymes involved in the degradation of $\mathrm{H}_{2} \mathrm{O}_{2}$ (SOD and CAT) was also reduced. In the literature, there are no other studies that examine $\mathrm{H}_{2} \mathrm{O}_{2}$ levels in similar conditions, which provides us with a limited explanation of these results.

Because ROS have extremely short half-lives, they are difficult to measure directly. Instead, what can be measured are several products of the damage due to oxidative stress, as in the TBARS assay (32). TBARS assay values are usually reported in malondialdehyde (MDA) equivalents, a compound that is a result of the decomposition of polyunsaturated fatty acid lipid peroxides. The TBARS assay is a wellrecognized, established method for quantifying these lipid peroxides, although it has been criticized for its reactivity with compounds other than MDA (32). Although there has been an increase in TBARS values in patients with fractures, this increase was not statistically significant (Figure 3). Wang and colleagues also showed an increase in this parameter in elderly patients with femoral neck fractures (2). In their study, they investigated the value of TBARS in younger patients with femur fractures and have obtained results that show a statistically significant increase unlike those observed in elderly patients. The difference in average age between the patients in our study (66 years old) and their study (86 years old), is approximately 20 years, and could be one of the reasons why our results did not show a statistically significant increase in TBARS values.

The concentration of nitric oxide in physiological conditions is low (33). In our study, the measurement of $\mathrm{NO}_{2}$ - levels was lower in the experimental group (Figure 4), which may be due to the interaction of $\mathrm{NO}_{2}^{-}$with several free radicals (34). Sandukji and colleagues suggest that the excessive production of free radicals occurs three days after the fractures, and one of the reasons for the observed decline may be because the $\mathrm{NO}_{2}$ - levels were measured too soon (31).

However, it can also be expected that fracture causes changes in the antioxidative enzymatic system. Therefore, we investigated the activity of three major antioxidative enzymes, CAT, SOD and GSH, to create a complete picture of the redox state in patients with femoral neck fractures.

Superoxide dismutase is the most abundant antioxidant enzyme and its main role is to catalyse the neutralization of superoxide anions (35). A study that was carried out in France in the early 1990's recorded a significant decrease in the levels of this enzyme in older patients (36), which is consistent with the theory that connects the free radi- 
cals and the process of aging (23). In our study, there was a drastic decline in the SOD concentrations in the experimental group compared to the control group (Figure 5). Many researchers believe that the reason for the low concentrations of this enzyme in patients with femoral neck fractures is the excessive production of superoxide anion radicals $(37,38)$. Specifically, osteoclasts lead to an increased production of $\mathrm{O}_{2}$, which is catalysed by SOD, and cause a reduction in the levels of the enzyme antioxidant defence system (34).

Moreover, CAT decomposes $\mathrm{H}_{2} \mathrm{O}_{2}$ to $\mathrm{H}_{2} \mathrm{O}$ and $\mathrm{O}_{2}$ (29). Our results showed that there was a statistically significant decline of this enzyme in the experimental group (Figure 6). Although the literature mentions a possible decline of antioxidant enzymes during femur fractures (33), there are no studies that specifically examine the values of parameters such as the CAT and GSH levels. Glutathione peroxidase, like CAT, protects cells from hydrogen peroxide. Additionally, our results suggest that the fracture of the femur leads to a drop in GSH levels (Figure 7). However, this is not as drastic as the decrease in CAT levels. One possible explanation for the present imbalance between pro-oxidants and antioxidants in patients with hip fracture is the combined effect of the reduced activity of osteoblasts and the increased activity of osteoclasts. Decreased activity of all the measured antioxidants is difficult to explain, keeping in mind the lack of data in the existing literature. However, one of the potential mechanisms for these results could be a loss of caspase- 2 activity during bone fracture, which leads to a reduction in the expression of antioxidant genes (40).

Considering all these results of the present study together may help to better understand the molecular mechanisms involved in femoral neck (hip) fractures. These findings could be of clinical interest and enable the implementation of antioxidant supplements as adjuvant therapy in these patients.

\section{REFERENCES}

1. Gdalevich M, Cohen D, Yosef D, Tauber C. Morbidity and mortality after hip fracture: the impact of operative delay. Archives of orthopaedic and trauma surgery. 2004; 124:334-40.

2. Wang Z, Ehnert $\mathrm{S}$, Ihle $\mathrm{C}$, et al. Increased oxidative stress response in granulocytes from older patients with a hip fracture may account for slow regeneration. Oxid Med Cell Longev. 2014; 2014:819847.

3. Babic RR, Mladenovic M, Mladenovic D, et al. Kostolom greater trochanter - Radiological - clinical picture. Apollinem medicum et aesculapium. 2014; 12:7-18.

4. Maggi S, Kelsey JL, Litvak J, Heyse SP. Incidence of hip fracture in the elderly: A cross-national analysis. Osteoporosis Int 1991; 1:232-41.

5. Zhang L, Cheng A, Bai Z, et al. Epidemiology of cervical and trochanteric fractures of the proximal femur in 1994 in Tangshan, China. J Bone Miner Metab 2000; 18:84-8.
6. Keene GS, Parker MJ, Pryor GA. Mortality and morbidity after hip fractures. Bmj. 1993; 307:1248-50.

7. Rubin CD. Evaluation and management of hip fracture risk in the aged. American Journal of the Medical Sciences. 2012; 343:233-42.

8. Icks A, Haastert B, Glaeske G, Stumpf U, Windolf J, Hoffmann F. Correction factor for the analysis of the hip fracture incidence-differences between age, sex, region, and calendar year. Wiener klinische Wochenschrift. 2012; 124:391.

9. Banfi G, Iorio EL, Corsi MM. Oxidative stress, free radicals and bone remodeling. Clin Chem Lab Med. 2008; 46:1550-5.

10. Basu S, Michaëlsson K, Olofsson H, Johansson S, Melhus $\mathrm{H}$. Association between oxidative stress and bone mineral density. Biochemical and biophysical research communications. 2001; 288:275-9.

11. Jyoti A, Singh S, Mukhopadhyay B, Gavel R, Mishra SP. Free radicals and antioxidant status in chronic osteomyelitis patients: a case control study. J Clin Diagn Res. 2015; 4:8-10.

12. Yeler H, Tahtabas F, Candan F. Investigation of oxidative stress during fracture healing in the rats. Cell biochemistry and function, 2005; 23:137-9.

13. J. M. McCord and I. Fridovich, "The utility of superoxide dismutase in studying free radical reactions. I. Radicals generated by the interaction of sulfite, dimethyl sulfoxide, and oxygen," Journal of Biological Chemistry, vol. 244, no. 22, pp. 6056-6063, 1969.

14. Auclair C, Voisin E. Nitrobluetetrazolium reduction. In: Greenwald RA, ed. Handbook of methods for oxygen radical research. Boca Raton; CRP Press 1985; 123-32.

15. Pick E, Keisari Y. A simple colometric method for the measurement of hydrogen peroxide by cells in culture. J Immunol Methods 1980; 38:161-170.

16. Ohkawa H, Ohishi N, Yagi K. Assay for lipid peroxides in animal tissues by thiobarbituric acid reaction. Anal. Biochem. 1979; 95:351-358.

17. Green LC, Wagner DA, Glogowski J, Skipper PI, Wishnok JS, Tannenbaum SR. Analysis of nitrate, nitrite and [15N] nitrate in biological fluids. Anal Biochem 1982; 126:131-8.

18. Misra HP, Fridovich I. The role of superoxide anion in theautoxidation of epinephrine and a simple assay for superoxidedismutase. J BiolChem 1972; 247:3170-5.

19. McCord JM, Fridovich I. Superoxide dismutase. An enzymic function for erythrocuprein (hemocuprein). J Biol Chemi 1969; 244:6049-55.

20. Beutler E. Catalase. In: Butler E, ed. Red cell metabolism. A manual of biochemical methods. New York: Grune and Stratton. 1982; 105-6.

21. Tsuchihashi M. Zur Kernntnis der blutkatalase. Biochem Zeits 1923; 140:65-72.

22. Beutler, E. Reduced glutathione (GSH). In Red cell metabolism, a manual of biochemical methods. Edited by Beutler, E. Grune and Stratton, New York. 1975; pp. 112-4. 
23. Karaca S, Ayhan E, Kesmezacar H, Uysal O. Hip fracture mortality: is it affected by anesthesia techniques? Anesthesiol Res Pract. 2012; 2012:708754.

24. Beckman KB, Ames BN. The free radical theory of aging matures. Physiological Reviews. 1998; 78:547-81.

25. Salmon AB, Richardson A, Pérez VI. Update on the oxidative stress theory of aging: does oxidative stress play a role in aging or healthy aging? Free Radical Biology and Medicine. 2010; 48:642-55.

26. Radovanović D, Ranković G. Oxidative stress, stress proteins and antioxidants in exercise. Acta Medica Medianae, 2004; 43:45-7.

27. Butcher SK, Killampalli V, Chahal H, Kaya Alpar E, Lord JM. Effect of age on susceptibility to post-traumatic infection in the elderly. Biochem. Soc. Trans. 2003; 31:449-51.

28. Hazeldine J, Arlt W, Lord JM. Dehydroepiandrosterone as a regulator of immune cell function. J. Steroid Biochem. Mol. Biol. 2010; 120:127-36.

29. Nathan CF. Secretory products of macrophages. J Clin Investig 1987; 79:319-26.

30. Datta HK, Manning P, Rathod H, McNeil C. Effect of calcitonin, elevated calcium and extracellular matrices on superoxide anion production by rat osteoclasts. Exp Physiol. 1995; 80:713-9.

31. Datta HK, Rathod H, Manning P, Turnbull Y, McNeil CJ. Parathyroid hormone induces superoxide anion burst in the osteoclast: evidence for the direct instantaneous activation of the osteoclast by the hormone. J Endocrinol. 1996; 149:269-75.
32. Parola M, Robino G. Oxidative stress-related molecules and liver fibrosis. J Hepatol. 2001; 35:297-306.

33. Pryor WA. The antioxidant nutrients and disease prevention--what do we know and what do we need to find out? Am J Clin Nutr 1991; 53:391-3.

34. Džoljić E, Nesic SI, Stojanovic RM, et al. Nitrous oxide, neurodegeneration and Parkinson's disease. Case report. 2005; 62:751-6.

35. Sandukji A, Al-Sawaf H, Mohamadin A, Alrashidi Y, Sheweita SA. Oxidative stress and bone markers in plasma of patients with long-bone fixative surgery: role of antioxidants. Hum Exp Toxicol. 2011; 30:435-42.

36. Choi JH, Yu BP. Brain synaptosomal aging: Free radicals and membrane fluidity - Free Radic Biol Med. 1995; 18:133-9.

37. Guemouri L, Artur Y, Herbeth B, Jeandel C, Cuny G, Siest G. Biological variability of superoxide dismutase, glutathione peroxidase, and catalase in blood. Clin Chem. 1991; 37:1932-7.

38. Sheweita SA, Koshhal K. Calcium metabolism and oxidative stress in bone fractures: role of antioxidants. Current Drug Metabolism. 2007; 8:519-25.

39. Beharka AA, Han SN, Adolfsson O, Wu D, Smith D, Lipman $\mathrm{R}$, et al. Long-term dietary antioxidant supple- mentation reduces production of selected inflamma- tory mediators by murine macrophages. Nutr Res. 2000; 20:281-96.

40. Sharma R, Callaway D, Vanegas D, Bendele M, LopezCruzan M, Horn D, Guda T, Fajardo R, Abboud-Werner S, Herman B. Caspase-2 maintains bone homeostasis by inducing apoptosis of oxidatively-damaged osteoclasts. PLoS One. 2014 Apr 1;9(4):e93696. 


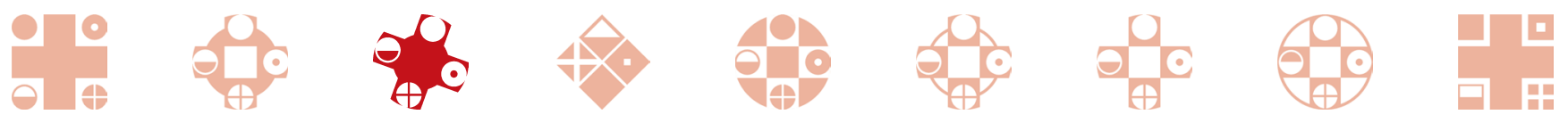

